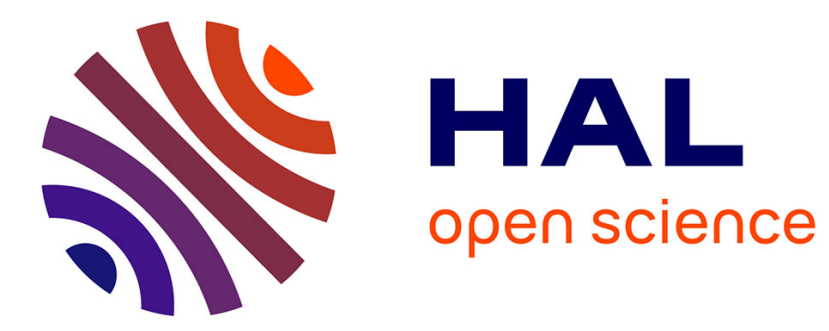

\title{
Stratospheric smoke with unprecedentedly high backscatter observed by lidars above southern France
}

Sergey Khaykin, Sophie Godin-Beekmann, Alain Hauchecorne, Jacques Pelon, François Ravetta, Philippe Keckhut

\section{- To cite this version:}

Sergey Khaykin, Sophie Godin-Beekmann, Alain Hauchecorne, Jacques Pelon, François Ravetta, et al.. Stratospheric smoke with unprecedentedly high backscatter observed by lidars above southern France. Geophysical Research Letters, 2018, 45 (3), pp.1639-1646. 10.1002/2017GL076763 . insu-01692336

\section{HAL Id: insu-01692336 \\ https://hal-insu.archives-ouvertes.fr/insu-01692336}

Submitted on 19 Jul 2020

HAL is a multi-disciplinary open access archive for the deposit and dissemination of scientific research documents, whether they are published or not. The documents may come from teaching and research institutions in France or abroad, or from public or private research centers.
L'archive ouverte pluridisciplinaire HAL, est destinée au dépôt et à la diffusion de documents scientifiques de niveau recherche, publiés ou non, émanant des établissements d'enseignement et de recherche français ou étrangers, des laboratoires publics ou privés. 


\section{Geophysical Research Letters}

\section{RESEARCH LETTER}

10.1002/2017GL076763

Key Points:

- North American wildfires during

summer 2017 and intense

pyroconvection pollute the

stratosphere with smoke

- Stratospheric smoke plumes detected by ground-based and spaceborne lidars feature unprecedentedly high backscatter and aerosol optical depth

- Summer 2017 wildfires had a

hemisphere-scale impact on

stratospheric aerosol load similar to

that of moderate volcanic eruptions

Supporting Information:

- Supporting Information S1

- Supporting Information S2

Correspondence to:

S. M. Khaykin,

sergey.khaykin@latmos.ipsl.fr

\section{Citation:}

Khaykin, S. M., Godin-Beekmann, S., Hauchecorne, A., Pelon, J., Ravetta, F., \& Keckhut, P. (2018). Stratospheric smoke with unprecedentedly high backscatter observed by lidars above southern France. Geophysical Research Letters, 45, 1639-1646. https://doi.org/10.1002/ 2017GL076763

Received 14 DEC 2017 Accepted 21 JAN 2018 Accepted article online 24 JAN 2018 Published online 6 FEB 2018

\section{Stratospheric Smoke With Unprecedentedly High Backscatter Observed by Lidars Above Southern France}

\author{
S. M. Khaykin ${ }^{1}$ (D, S. Godin-Beekmann ${ }^{1}$ iD, A. Hauchecorne' ${ }^{1}$ D, J. Pelon ${ }^{1}$, F. Ravetta ', \\ and P. Keckhut ${ }^{1}$ \\ 'LATMOS/IPSL, UVSQ Université Paris-Saclay, UPMC University Paris 06, CNRS, Guyancourt, France
}

\begin{abstract}
Extreme pyroconvection events triggered by wildfires in northwest Canada and United States during August 2017 resulted in vast injection of combustion products into the stratosphere. The plumes of stratospheric smoke were observed by lidars at Observatoire de Haute-Provence (OHP) for many weeks that followed the fires as distinct aerosol layers with backscatter reaching unprecedentedly high values for a nonvolcanic aerosol layer. We use spaceborne CALIOP lidar to track the spatiotemporal evolution of the smoke plumes before their detection at OHP. A remarkable agreement between ground- and spaced-based lidars sampling the same smoke plume on a particular date allowed us to extrapolate the OHP observations to a regional scale, where CALIOP reported extreme aerosol optical depth values as high as 0.21 . On a monthly time scale, the lidar observations indicate that boreal summer 2017 forest fires had a hemisphere-scale impact on stratospheric aerosol load, similar to that of moderate volcanic eruptions.
\end{abstract}

Plain Language Summary Stratospheric aerosol plays a large role in global climate through negative radiative forcing. Volcanic eruptions are considered the major source of stratospheric aerosol. In the absence of strong eruptions, the permanent stratospheric aerosol layer is commonly attributed to sulphuric gases emitted at the surface and lofted into the stratosphere by deep convection. Recent studies have put in evidence that biomass burning is an important contributor to stratospheric aerosol budget. During Summer 2017, severe forest wildfires raged in North America, resulting in pyrocumulonumbus firestorms injecting large amounts of smoke and combustion products into the stratosphere. The smoke has been dispersed throughout a large part of northern hemisphere in a few weeks. The observations using ground-based and space-borne laser radars (lidars) indicate that the smoke layer had an unprecedentedly high optical depth for a non-volcanic aerosol layer. On a monthly time scale, the boreal summer 2017 forest fires had a hemisphere-wide impact on stratospheric aerosol load, similar to that of moderate volcanic eruptions. This study emphasizes the significance of biomass burning as a source of stratospheric aerosol and provides an opportunity for re-evaluating the potential of wildfires to pollute the stratosphere.

\section{Introduction}

Among the nonvolcanic contributors to stratospheric aerosol load, biomass burning is an important one. A number of case studies have provided evidence that pyroconvection triggered by intense forest or bush fires is capable of polluting the stratosphere with combustion products on a hemispheric scale (Cammas et al., 2009; Damoah et al., 2006; Fromm et al., 2000, 2005, 2006; Fromm, Torres, et al., 2008; Pumphrey et al., 2011; Siddaway \& Petelina, 2011). The mechanism of vertical transport of smoke and soot into the stratosphere is said to be either direct injections by pyrocumulonimbus (PyroCb) convection (Fromm \& Servranckx, 2003; Jost et al., 2004) and/or radiatively driven uplift from the troposphere (de Laat et al., 2012; Radke et al., 1990), depending on the local meteorological conditions (Kremser et al., 2016). Over the last decade, the interest to stratospheric effect of wildfires has increased and so has the amount of evidence reported (Fromm et al., 2010, and references therein). With that, the observational material on such events is still lacking, especially high vertical resolution data.

Severe forest wildfires in northwest Canada and United States raged during July-August 2017. In early August, a large cluster of fires flared up near the Lake Athabasca (NASA Earth Observatory, 2017). The smoke was streaming north and northeast, while its plume was thick enough to break a record. The Ozone Mapping and Profiling Suite (OMPS) on board Suomi NPP satellite recorded aerosol index (AI) value of 49.7 on 15 August (Seftor, 2017a), which is about 30\% higher than the previous record values observed after 
Australian Black Saturday fires in 2006 (Fromm et al., 2006) and Canadian Chisholm fires in 2001 (Fromm, Torres, et al., 2008). Note that $\mathrm{Al}$ is strongly dependent not only on the plume's optical thickness but also on its altitude (Torres et al., 1998). The observed extreme Al values suggest that the smoke plume has been uplifted above the tropopause, where it can be entrained and dispersed zonally by polar jet stream.

The stratospheric aftermath of intense PyroCb events is usually surveyed using nadir and limb viewing satellite instruments as well as ground-based, airborne, and balloon-borne sensors. This study documents the observations of stratospheric smoke plume by lidars at Observatoire de Haute-Provence (OHP) in southern France during 5 weeks that followed the major PyroCb event in mid-August. Using Cloud-Aerosol Lidar and Infrared Pathfinder Satellite Observations (CALIPSO) lidar observations, we attempt to characterize the spatiotemporal evolution of the smoke plume in the stratosphere prior to its detection by ground-based lidars. At that, we do not investigate here the initial stratospheric injection scenario nor the composition of the smoke plume.

\section{Instruments}

\subsection{OHP Lidars}

The OHP located in southern France $\left(43.9^{\circ} \mathrm{N}, 5.7^{\circ} \mathrm{E}, 670 \mathrm{~m}\right)$ is one of the Alpine stations of the Network for Detection of Atmospheric Composition Change. The site is equipped with several lidar systems for atmospheric sounding at a wide range of altitudes. The longest continuous lidar data records at OHP are provided by two independent instruments: a differential absorption lidar for stratospheric ozone (hereafter referred to as LiO3S) with an off-line channel of $355 \mathrm{~nm}$ and a Rayleigh-Mie lidar for temperature and aerosol measurements (hereafter referred to as LTA) operating at $532 \mathrm{~nm}$.

Both LiO3S (Godin-Beekmann et al., 2003) and LTA (Keckhut et al., 1993) lidar systems have provided routine measurements for over 3 decades with a mean measurement rate of 10-12 acquisition nights per month. The two lidars are operated quasi-simultaneously and a typical acquisition lasts for $3-5 \mathrm{~h}$.

For retrieving vertical profiles of stratospheric aerosol, we use LiO3S and LTA elastic channels at $355 \mathrm{~nm}$ and $532 \mathrm{~nm}$, respectively, and apply Fernald-Klett inversion method (Fernald, 1984; Klett, 1985), which provides backscatter and extinction coefficients. The scattering ratio for the two wavelengths $\left(\mathrm{SR}_{355}\right.$ and $\left.\mathrm{SR}_{532}\right)$ is then computed as a ratio of total (molecular plus aerosol) to molecular backscattering, where the latter is derived from National Centers for Environmental Prediction meteorological data. The resulting vertical profiles of aerosol parameters are reported at $150 \mathrm{~m}$ vertical resolution. A more detailed description of the instruments, aerosol retrieval, and error budget is provided by Khaykin et al. (2017, and references therein).

\subsection{CALIOP}

CALIOP (Cloud-Aerosol Lidar with Orthogonal Polarization) is a nadir-viewing active sounder on board CALIPSO satellite, providing measurements of elastic backscatter at $532 \mathrm{~nm}$ and 1,064 $\mathrm{nm}$. (Winker et al., 2010). The data used here are based on nighttime $532 \mathrm{~nm}$ level 1B version 3.4 expedited product, which includes calibrated attenuated backscatter along with collocated meteorological information provided by the National Aeronautics and Space Administration Global Modeling and Assimilation Office (GMAO). After downsampling of the original attenuated backscatter measurements to $50 \mathrm{~km}$ horizontal and $150 \mathrm{~m}$ vertical resolution, the data were postprocessed using a treatment described in detail by Vernier et al. (2009).

In a nutshell, this treatment consists in the following. First, the total attenuated backscatter profiles are corrected for molecular attenuation and ozone absorption using collocated GMAO air and ozone density profiles. The SR is then calculated as the ratio of total and molecular backscatter coefficients, with the latter derived from GMAO air density profiles. The resulting SR profiles are recalibrated at $36-39 \mathrm{~km}$ altitude range following closely Vernier et al. (2009). For calculation of aerosol optical depth (AOD) the backscatter data are converted to aerosol extinction using lidar ratio of $70 \mathrm{sr}$, a value assumed for smoke in CALIPSO automated retrieval (Omar et al., 2009).

\section{Observations of Smoke at OHP}

We examine OHP lidar observations over the period 16-26 September 2017, which includes 20 nights of measurements with both lidars. The smoke plume was detected at OHP for the first time on 24 August as 


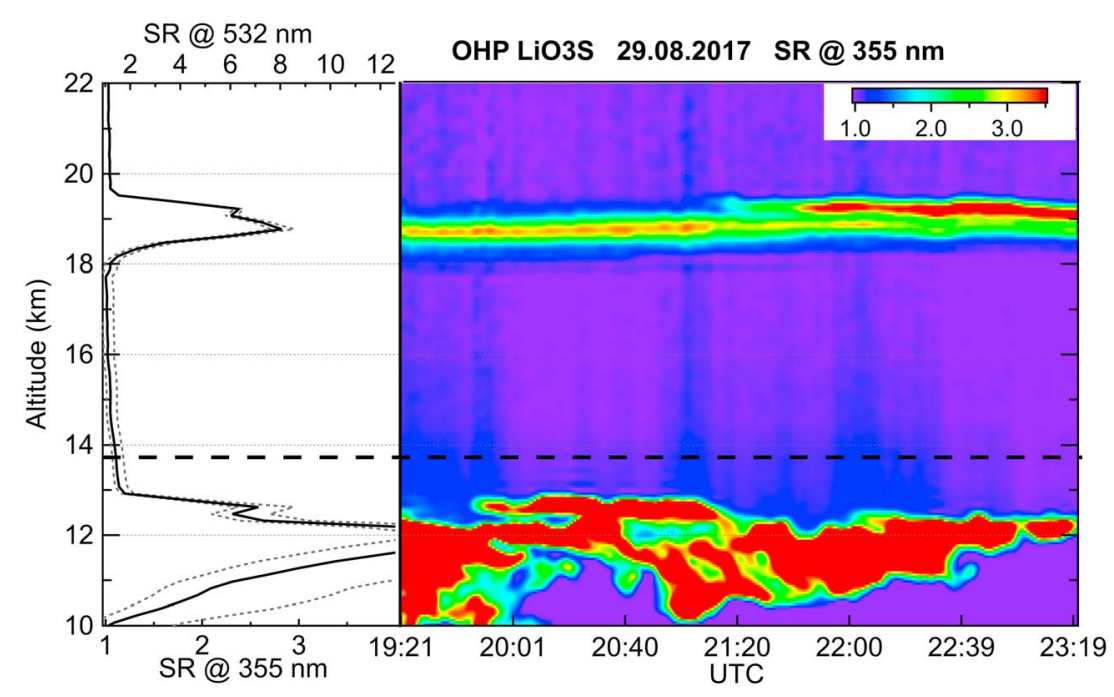

Figure 1. Nightly mean (left) and time curtain (right) of scattering ratio (SR) profile obtained on 29 August by OHP LiO3S lidar (355 nm). Horizontal black dashed line marks the thermal tropopause (ECMWF). The top axis in the left panel, representing SR at $532 \mathrm{~nm}$, is scaled using Ångström exponent within the smoke layer (0.78) derived from simultaneous measurements at two wavelengths. Gray dashed lines bound an envelope of SR profiles obtained by varying lidar ratio from 20 to 80 (upper and lower boundary respectively).

a $1 \mathrm{~km}$ thick layer centered at $14.9 \mathrm{~km}$ altitude. Between 24 August and 26 September, the smoke was observed on 14 out of 15 measurement dates as distinct stratospheric layers with a peak $\mathrm{SR}_{532}$ between 1.2 and 10.0 appearing at different levels between 14.0 and $19.8 \mathrm{~km}$ altitude. The lidar observations over the period of interest are summarized in Table S1 in supporting information. The nightly mean and timeresolved SR profiles for selected nights are provided in Figure S1.

Figure 1 displays the measurements on 29 August that is when the smoke layer above OHP obtains maximum elevation, SR, and optical depth. The time curtain of SR reveals a multilayered cirrus cloud in the upper troposphere and a double-peak layer of stratospheric smoke whose vertical structure varies over the course of the $4 \mathrm{~h}$ long sounding.

The SR profiles in Figure 1 were derived assuming a constant lidar ratio of $50 \mathrm{sr}$, a default value commonly used for stratospheric aerosol. The gray dashed envelope around the nightly mean SR profile in the left-hand panel indicates the uncertainty associated with the unknown lidar ratio. This envelope shows that by varying lidar ratio from 20 to 80 the SR values vary considerably within the cirrus cloud; however, the effect of lidar ratio on the smoke layer's SR is very small. It should be noted though that the error in retrieved aerosol extinction and AOD is directly proportional to that of lidar ratio.

\subsection{Comparison of 29 August OHP Observations With CALIOP}

Among all the cases of stratospheric smoke detection at OHP, the measurement on 29 August featured the nearest in time and space overpass of CALIPSO lidar sampling the same smoke plume. Figure $2 a$ maps the CALIPSO track across the plume with indication of plume occurrence along the orbit color coded by smoke layer's AOD. Superimposed is the time-correspondent wind field at $19 \mathrm{~km}$ from European Centre for MediumRange Weather Forecasts (ECMWF) operational analysis. The time difference between OHP lidars and CALIOP sampling is $3-5 \mathrm{~h}$, with the latter passing $180 \mathrm{~km}$ at the nearest point east-southeast from OHP.

Figure $2 \mathrm{~b}$ displays the corresponding CALIOP latitude-altitude curtain of SR revealing a highly backscattering layer appearing as a multistorey feature between 16 and $20 \mathrm{~km}$ altitude. The core of this plume is observed between $470 \mathrm{~K}$ and $500 \mathrm{~K}$ isentropes with $\mathrm{SR}_{532}$ reaching 18.2 at $43.9^{\circ} \mathrm{N}$.

Figure 2c compares the nightly mean SR profile from LTA $(532 \mathrm{~nm}$ ) lidar (solid blue) against the CALIOP SR profile (red) averaged between the vertical dashed lines in Figure $2 \mathrm{~b}$. The CALIOP stratospheric SR profile above and below the apparent smoke layer was obtained by averaging along $\pm 5^{\circ}$ latitude band to reduce noise. The ground- and space-based lidars reveal a remarkable agreement both in vertical structure and 
a)

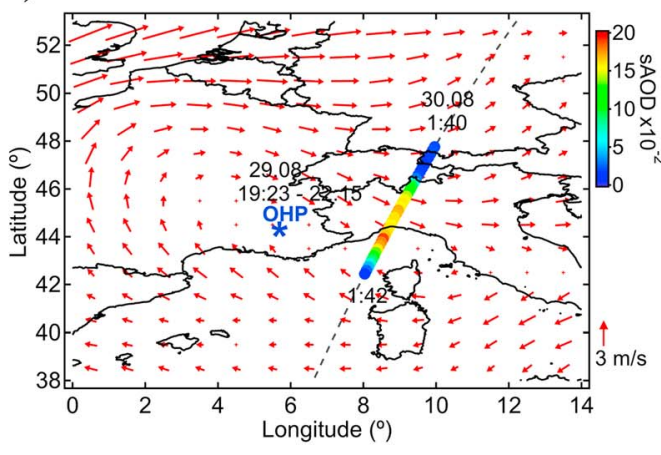

b)

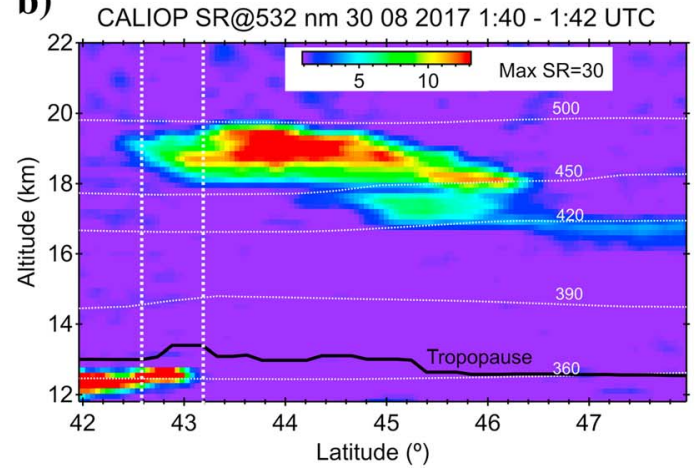

c)

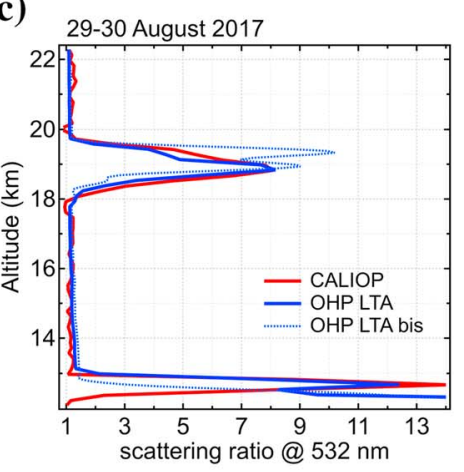

Figure 2. (a) CALIPSO track across the smoke plume in the proximity of OHP (black dashed line) with indication of plume occurrence along the track color coded by plume layer AOD. Red arrows indicate the wind field at $\sim 19 \mathrm{~km}$ from ECMWF T106 operational analysis on 30 August 00 UT; (b) Latitude-altitude curtain of SR from CALIOP on 30 August along its track shown in Figure 2a. Horizontal dashed lines indicate isentropic levels (GMAO), vertical dashed lines bound the part of CALIPSO track upwind of and nearest to OHP; (c) Comparison of SR vertical profiles from CALIOP (average between 42.6 and $43.2^{\circ} \mathrm{N}$, i.e., within white dashed lines in Figure 2a) and OHP LTA (532 nm) lidar nightly mean (29 August 19:23-22:15 UT, solid curve). Dashed blue curve (OHP LTA bis) represents SR profile from the late part of LTA measurement session (21:40-22:15 UT).

the peak $\mathrm{SR}_{532}$ value of the smoke layer as observed at OHP and upwind. Note the very weak wind in that area, suggesting that OHP lidars and CALIOP have most likely sampled the same air mass, entrained by anticyclonic circulation pattern centered roughly above OHP.

The above inference is supported by the similarities in temporal and latitudinal SR curtains in Figures 1 and 2b. CALIOP curtain shows a transition to double-peaked structure of the smoke layer toward northeast of the track, which is reflected by the double-peak structure of layer during the late part of OHP measurement session (LTA bis profile in Figure 2c).

\section{Spatiotemporal Evolution of the Smoke Plume From CALIOP}

Here we use CALIOP nighttime measurements spanning 12 August through 3 September to provide a global perspective on the evolution of the smoke plume in space and time. Note that CALIOP operation was suspended 5 through 14 September due to increased solar activity.

Detection of the smoke plume in CALIOP data was done using SR profiles. The smoke layer for a given vertical profile was said present if SR exceeds 1.8 in a layer thicker than $450 \mathrm{~m}$ located $300 \mathrm{~m}$ above the local GMAO tropopause. To avoid aliasing cirrus clouds above the thermal tropopause, the data with depolarization larger than $30 \%$ were discarded. The results of automated smoke detection procedure were successfully validated through manual examination of CALIOP curtains along each orbit.

\subsection{Horizontal Transport}

Figure 3a shows the locations of smoke layer along CALIPSO tracks color coded as a function of date since the first detection. The AOD of the smoke layer and date-sorted areas where OMPS recorded Al values greater than 7 can be inferred from Figure $3 \mathrm{~b}$. The first unambiguous occurrence of the smoke in the stratosphere was on 16 August, when it emerged at and above the tropopause between $\sim 11$ and $14 \mathrm{~km}$ northeast and downwind of the major fire spots around Athabasca Lake and attained AOD of 0.43. For comparison, the background AOD of the entire stratosphere is 0.004 (Khaykin et al., 2017). Note also that AOD estimates for the thickest plume occurrences are underestimated since we neglect extinction by aerosols in CALIOP data treatment.

Over the following 3 days, the smoke advances rapidly eastward and southeastward carried by the stratospheric flow. There appears to be several parts of the smoke plume, traveling at different speed, of which the core part with extreme AOD up to 0.7 is seen above Labrador Peninsula on 19 August. The secondary smoke tongues with lower AOD are traveling faster, crossing the Atlantic via northern and southern routes. By 19 August the forefront plume is seen above France, whereas by 20 August it has already advanced to northwest Siberia. 

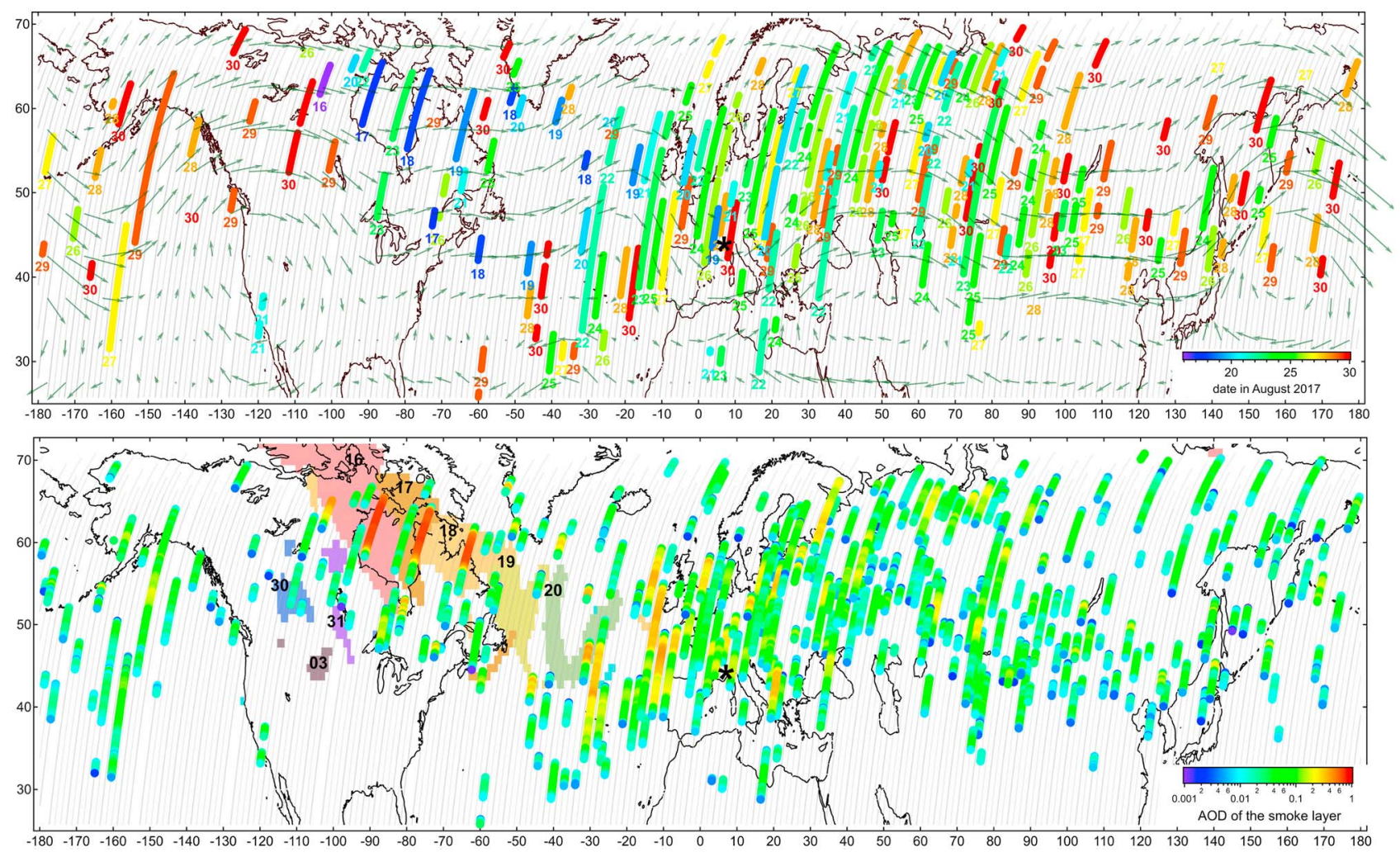

Figure 3. (a) Locations of smoke layer along CALIPSO nighttime orbits during the period 14-30 August color coded as a function of date since the first stratospheric detection of plume (16 August). The numbers below each colored track indicate the date in August. The superimposed ECMWF wind field represents a mean between 70 and $100 \mathrm{hPa}$ over 16-22 August period. Black asterisk mark OHP location. (b) Same as Figure 3a but including CALIOP data up until 3 September and color coded by the smoke layer's AOD. Color filled areas indicate the occurrences of Al values above 7 with indication of the day in August and September.

The primary plume is advected southeastward across the Atlantic while expanding meridionally. On 22 August, a large patch spanning 39 to $60^{\circ} \mathrm{N}$ approaches Europe from southwest. Having stretched from Mediterranean to Baltic seas, it travels further east following the pattern of zonal circulation with the Asian monsoon anticyclone rerouting the smoke-laden air masses northward. By 30 August, that is 14 days since the stratospheric intrusion, the plume had already circled the globe, reappearing above northwest Canada.

The above interpretation of the plume evolution is supported and further clarified by a series of daily maps (provided in the supporting information) of stratospheric plume locations superimposed onto UV AI maps from OMPS instrument. The daily maps suggest that the primary smoke plume (with extreme Al values exceeding 30) has parted completely North America by 20 August; however, an area of elevated Al remained above Canadian Arctic and was advected southeast over Hudson Bay during 20-24 August. This can explain the plume patches seen by CALIOP above different parts of North America during these days, that is, out of phase with the spatiotemporal progression of the major smoke plume. Note that since we restrict the analysis to nighttime CALIOP measurements, the smoke patches in the Arctic were missed.

Further examination of daily maps leads to an inference on the additional, later episodes of smoke intrusion into the stratosphere during late August. Patches of elevated Al (up to 23) maximizing 30-31 August above central Canada were most certainly caused by wildfires in Northern California and Oregon and related PyroCB events in late August (Seftor, 2017b). Indeed, the stratospheric plume occurrences above North America detected by CALIOP on 30 August to 1 September match in space in time with the Al cloud as it was advected east across the continent.

\subsection{Three-Dimensional Evolution}

Figure 4 provides an insight into three-dimensional evolution of the smoke plume. A Hovmoller plot in Figure 4a displays zonal progression of the smoke plume since its first detection on 16 August with indication of the potential temperature of the layer's maximum SR. It is obvious from the figure that the plumes residing 
a)

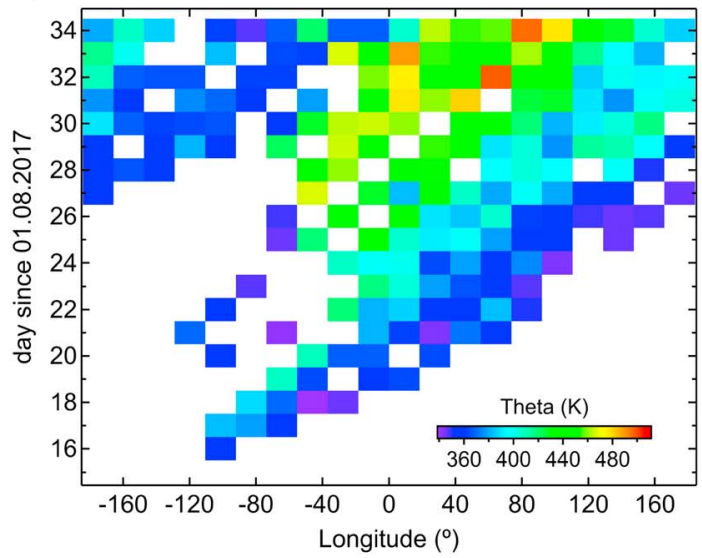

b)

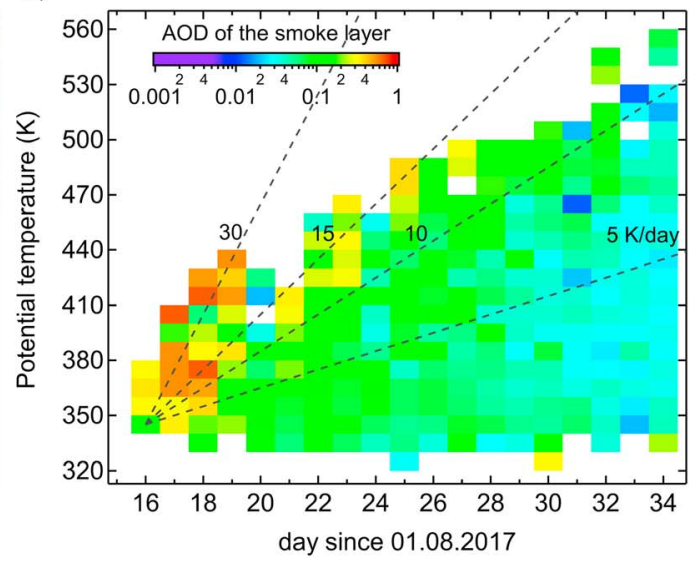

Figure 4. (a) Zonal-temporal evolution of the smoke plume detected by CALIOP with color coding by potential temperature of maximum SR within the smoke layer. (b) Vertical (cross-isentropic) dispersion of the smoke plume with color coding by the AOD of the smoke layer. Dashed lines indicate diabatic heating rates.

at lower isentropic levels are subject to faster zonal transport within the polar jet stream. Meanwhile, the plumes that have ascended to higher levels travel slower because of a strong wind shear in the lower stratosphere. Indeed, the zonal mean zonal wind at northern midlatitudes (not shown) decreases from $\sim 15 \mathrm{~m} / \mathrm{s}$ at $150 \mathrm{hPa}$ to $\sim 3 \mathrm{~m} / \mathrm{s}$ at $70 \mathrm{hPa}$.

Another important inference from Figure $4 \mathrm{a}$ is that around the longitude of $\mathrm{OHP}\left(5.7^{\circ} \mathrm{E}\right)$ the smoke is present virtually each night since 19 August, occurring at various levels, from $360 \mathrm{~K}$ to $490 \mathrm{~K}$. The early smoke's occurrences above this region reflect the passage of low-level vanguard plumes carried by the jet stream, which are eventually alternated by slower-traveling plumes at higher levels. This is reflected in OHP observations evidencing a rise of smoke layer's altitude from 24 to 29 August (Table S1).

The origin of smoke layers observed at OHP on different dates was investigated using HYSPLIT model (see Figure S2 and related text in the supporting information). Backward trajectories show that the smoke layer at around $380 \mathrm{~K}$ isentropic level detected at OHP on 24 and 28 August is traceable to the major smoke spots (high-Al clouds) above northern Canada (16-18 August) caused by Athabasca fires. The stronger smoke layers observed at OHP on 29 August and 1 September at higher levels (430-460 K) could not be traced directly to high-Al plumes because of the substantial cross-isentropic excursion of the optically thick plume patches. However, these layers could be linked with thick high-level smoke patches detected by CALIOP above Atlantic Ocean on 22-23 August.

OHP smoke observation on 4 September was shown to match in time and space with high-Al cloud above central Canada on 1 September, associated with PyroCb events in Norther California and Oregon during the last week of August (Seftor, 2017b). The smoke detections at OHP posterior to 4 September are difficult to attribute to a particular PyroCb cluster due to coexistence of stratospheric plumes of different age by that time.

Figure $4 \mathrm{~b}$ shows temporal evolution of the plume in potential temperature space color coded by smoke layer's AOD. Evidently, the stratospheric smoke plume that emerged initially at $340 \mathrm{~K}-380 \mathrm{~K}$ has ascended rapidly over the first few days up to $440 \mathrm{~K}$ with a rate of about $30 \mathrm{~K} /$ day or $2-3 \mathrm{~km} / \mathrm{d}$, which is compatible with estimates of de Laat et al. (2012). The diabatic ascent of the smoke layer is presumed to be due to solar heating of the layer (Boers et al., 2010) and, expectedly, the optically thicker-more absorbing-layers are subject to larger heating and faster rise, as suggested by the color pattern in Figure 4b. Over 19 days of CALIOP observations of the smoke, the latter has ascended from $340 \mathrm{~K}(\sim 12 \mathrm{~km})$ to a maximum of $560 \mathrm{~K}(\sim 22 \mathrm{~km})$.

\section{Discussion and Summary}

Analysis of CALIOP and OMPS observations together with background wind flow and backward trajectories indicates that the stratospheric aerosol layers observed by OHP lidar during many weeks since late August are 
traceable to several PyroCb clusters triggered by intense wildfires in northwest Canada and United States. The most substantial stratospheric injection of smoke was caused by pyroconvection associated with forest fires around Athabasca Lake, Canada in mid-August, as suggested by OMPS and CALIOP observations. The stratospheric smoke plumes have dispersed all across the Northern Hemisphere extratropics in about 2 weeks, whereas the optically thick plume patches have been subject to substantial cross-isentropic ascent due to radiative heating of smoke aerosols.

CALIOP observations of the stratospheric smoke show that volume depolarization (ratio of the crosspolarized and parallel polarized backscatter, not shown) was larger than $10 \%$ over the entire period considered here. Such a high volume depolarization combined with high SRs leads to particulate depolarization ratios of about $15 \%$. This is a very unusual value for biomass burning particles (Omar et al., 2009), suggesting that mineral dust or irregularly shaped carbon particles have been uplifted into the stratosphere by the strength of pyroconvection.

Occurrence of stratospheric aerosol layers originating from remote forest fires has been reported for OHP in 1991 with $\mathrm{SR}_{532}$ up to 3 (Fromm et al., 2010) and other lidar stations across Europe in 2001 as layers with $\mathrm{SR}_{532}$ up to 2 (Fromm, Shettle, et al., 2008). In the present case, the smoke plume captured by OHP lidars attained a maximum $\mathrm{SR}_{532}$ of 10 . Such high stratospheric backscatter for a nonvolcanic aerosol layer is unprecedented in the OHP observation record dating back to early 1980s. Given that OHP site is a likely recipient of PyroCb stratospheric injections in the northern extratropics, the impact of wildfires on the stratosphere is supposed to be evenly sampled by regularly operated OHP lidars. The record-breaking lidar readings thus indicate the outstanding strength of stratospheric injections triggered by North American wildfires in 2017.

Stratospheric footprint of 2017 PyroCb events can be compared with that of moderate volcanic eruptions at northern midlatitudes. OHP observation record has been a witness to a period of moderate volcanic activity (2003-2015) including the eruption of Sarychev peak in 2009 that had a remarkable impact on stratospheric aerosol load across the Northern Hemisphere. With that, the AOD and SR of the smoke layer itself are $\sim 3$ times higher than the peak values of whole-stratosphere AOD recorded at OHP after Sarychev eruption (Khaykin et al., 2017). While the maximum AOD of the smoke layer reported by OHP LTA (532 nm) lidar amounts to 0.062 (assuming lidar ratio of $70 \mathrm{sr}$ ), CALIOP shows AOD values up to 0.21 above southern France (Figure $3 \mathrm{~b}$ ). For comparison, the peak values recorded at OHP after the eruption of El Chichon and Pinatubo volcanoes were 0.25 and 0.20 , respectively (Chazette et al., 1995). That said, we note that the global impact of 2017 wildfires is not to be compared with that of major eruptions.

When comparing optical properties of young smoke and volcanic plumes in the stratosphere, one should consider important differences in their aerosol composition. Smoke aerosol particles, composed of mineral dust, soot, and other carbonaceous material, are solid and can be characterized by highly irregular shape causing strong depolarization. Fresh volcanic aerosol is composed of sulfuric acid droplets and fine ash, leading, respectively, to low and high depolarization. The smoke particles with a large fraction of black carbon are by far more absorptive than sulfuric particles, which explains the remarkable radiative ascent of the smoke plume as witnessed by our observations.

While the microphysical properties of smoke and volcanic plumes are vastly different, it is of interest to compare the magnitude of bulk optical effect on the stratosphere resulting from wildfires and volcanism. On a monthly time scale, the whole-stratosphere AOD averaged over 30 days posterior to first detection of smoke at OHP (0.012) is closely comparable to monthly mean AOD values acquired at OHP after moderate volcanic eruptions at northern midlatitudes from the last two decades (0.01-0.014). On a hemispheric scale, the zonally and monthly averaged stratospheric AOD at midlatitudes $\left(30^{\circ}-60^{\circ} \mathrm{N}\right)$ from CALIOP observations during 16 August to 3 September period amounted to 0.01, which is about 3 times higher than the background level (Khaykin et al., 2017).

With the observations available to date, it is obvious that summer 2017 wildfires have left a notable footprint in the Northern Hemisphere stratospheric aerosol record, comparable to those following moderate volcanic eruptions. This event, emphasizing the significance of biomass burning as a source of stratospheric aerosol, provides a perfect opportunity for reevaluating the potential of wildfires to pollute the stratosphere and improving understanding of the underlying transport mechanisms, which needs to be addressed by further studies. 
Acknowledgments

We thank the personnel of OHP for conducting lidar measurements. The work was done with the support of French Institut National des Sciences de I'Univers (INSU) and of Centre National d'Etudes Spatiales (CNES). The following satellite data used in this study are publically available: CALIPSO, https:// eosweb.larc.nasa.gov/project/calipso/ calipso table and OMPS, https://ozoneaq.gsfc.nasa.gov/data/omps/ The OHP lidar data are currently available from a Dropbox folder https://www. dropbox.com/sh/bx270io06kth66f/ AABtiXhQWllqd2q4OBEds13Ca?dl $=0$ and will be permanently stored the NDACC data base, ftp://ftp.cpc.ncep. noaa.gov/ndacc/station/ohp/ames/ lidar.

\section{References}

Boers, R., de Laat, A. T., Stein Zweers, D. C., \& Dirksen, R. J. (2010). Lifting potential of solar-heated aerosol layers. Geophysical Research Letters, 37, L24802. https://doi.org/10.1029/2010GL045171

Cammas, J.-P., Brioude, J., Chaboureau, J. P., Duron, J., Mari, C., Mascart, P., ... Fromm, M. (2009). Injection in the lower stratosphere of biomass fire emissions followed by long-range transport: A MOZAIC case study. Atmospheric Chemistry and Physics, 9(15), 5829-5846. https://doi. org/10.5194/acp-9-5829-2009

Chazette, P., David, C., Lefrère, J., Godin, S., Pelon, J., \& Mégie, G. (1995). Comparative lidar study of the optical, geometrical and dynamical properties of the stratospheric post-volcanic aerosols following the eruption of El-Chichon and Mount Pinatubo. Journal of Geophysical Research, 100, 23,195-23,207. https://doi.org/10.1029/95JD02268

Damoah, R., Spichtinger, N., Servranckx, R., Fromm, M., Eloranta, E., Razenkov, I., ... Stohl, A. (2006). A case study of pyro-convection using transport model and remote sensing data. Atmospheric Chemistry and Physics, 6(1), 173-185. https://doi.org/10.5194/acp-6-173-2006

de Laat, A. T. J., Stein Zweers, D. C., Boers, R., \& Tuinder, O. N. E. (2012). A solar escalator: Observational evidence of the self-lifting of smoke and aerosols by absorption of solar radiation in the February 2009 Australian black Saturday plume. Journal of Geophysical Research, 117 D04204. https://doi.org/10.1029/2011JD017016

Fernald, F. G. (1984). Analysis of atmospheric lidar observations: Some comments. Applied Optics, 23(5), 652-653. https://doi.org/10.1364/ AO.23.000652

Fromm, M., Alfred, J., Hoppel, K., Hornstein, J., Bevilacqua, R., Shettle, E., ... Stocks, B. (2000). Observations of boreal forest fire smoke in the stratosphere by POAM III, SAGE II, and lidar in 1998. Geophysical Research Letters, 27, 1407-1410. https://doi.org/10.1029/1999GL011200

Fromm, M., Bevilacqua, R., Servranckx, R., Rosen, J., Thayer, J. P., Herman, J., \& Larko, D. (2005). Pyro-cumulonimbus injection of smoke to the stratosphere: Observations and impact of a super blowup in northwestern Canada on 3-4 August 1998. Journal of Geophysical Research 110, D08205. https://doi.org/10.1029/2004JD005350

Fromm, M., Lindsey, D. T., Servrqanckx, R., Yue, G., Trickl, T., Sica, R., ... Godin-Beekmann, S. (2010). The untold story of pyrocumulonimbus Bulletin of the American Meteorological Society, 91(9), 1193-1210. https://doi.org/10.1175/2010BAMS3004.1

Fromm, M., \& Servranckx, R. (2003). Transport of forest fire smoke, above the tropopause, supercell convection. Geophysical Research Letters, 30(10), 1542. https://doi.org/10.1029/2002GL016820

Fromm, M., Shettle, E. P., Fricke, K. H., Ritter, C., Trickl, T., Giehl, H., ... Deshler, T. (2008). Stratospheric impact of the Chisholm pyrocumulonimbus eruption: 2. Vertical profile perspective. Journal of Geophysical Research, 113, D08203. https://doi.org/10.1029/2007JD009147

Fromm, M., Torres, O., Diner, D., Lindsey, D., Vant Hull, B., Servranckx, R., ... Li, Z. (2008). Stratospheric impact of the Chisholm pyrocumulonimbus eruption: 1. Earth-viewing satellite perspective. Journal of Geophysical Research, 113, D08202. https://doi.org/10.1029/ 2007JD009153

Fromm, M., Tupper, A., Rosenfeld, D., Servranckx, R., \& McCrae, R. (2006). Violent pyro-convective storm devastates Australia's capital and pollutes the stratosphere. Geophysical Research Letters, 33, L05815. https://doi.org/10.1029/2005GL025161

Godin-Beekmann, S., Porteneuve, J., \& Garnier, A. (2003). Systematic DIAL lidar monitoring of the stratospheric ozone vertical distribution at Observatoire de Haute-Provence (43.92 $\left.{ }^{\circ} \mathrm{N}, 5.71^{\circ} \mathrm{E}\right)$. Journal of Environmental Monitoring, 5(1), 57-67. https://doi.org/10.1039/b205880d

Jost, H., Drdla, K., Stohl, A., Pfister, L., Loewenstein, M., Lopez, J. P., ... Xueref, I. (2004). In-situ observations of mid-latitude forest fire plumes deep in the stratosphere. Geophysical Research Letters, 31, L11101. https://doi.org/10.1029/2003GL019253

Keckhut, P., Hauchecorne, A., \& Chanin, M. L. (1993). A critical review on the data base acquired for the long term surveillance of the middle atmosphere by French Rayleigh lidars. Journal of Atmospheric and Oceanic Technology, 10(6), 850-867. https://doi.org/10.1175/ 1520-0426(1993)010\%3C0850:ACROTD\%3E2.0.CO;2

Khaykin, S. M., Godin-Beekmann, S., Keckhut, P., Hauchecorne, A., Jumelet, J., Vernier, J.-P., ... Bhartia, P. K. (2017). Variability and evolution of the midlatitude stratospheric aerosol budget from 22 years of ground-based lidar and satellite observations. Atmospheric Chemistry and Physics, 17(3), 1829-1845. https://doi.org/10.5194/acp-17-1829-2017

Klett, J. D. (1985). Lidar inversion with variable backscatter/extinction ratios. Applied Optics, 24(11), 1638-1643. https://doi.org/10.1364/ AO.24.001638

Kremser, S., Thomason, L. W., von Hobe, M., Hermann, M., Deshler, T., Timmreck, C., ... Meland, B. (2016). Stratospheric aerosolObservations, processes, and impact on climate. Reviews of Geophysics, 54, 278-335. https://doi.org/10.1002/2015RG000511

NASA Earth Observatory (2017). Record breaking smoke Above Canada. Retrieved from https://earthobservatory.nasa.gov/NaturalHazards/ view.php?id=90759, Access August 16.

Omar, A. H., Winker, D. M., Vaughan, M. A., Hu, Y., Trepte, C. R., Ferrare, R. A., ... Liu, Z. (2009). The CALIPSO automated aerosol classification and lidar ratio selection algorithm. Journal of Atmospheric and Oceanic Technology, 26(10), 1994-2014. https://doi.org/10.1175/ 2009JTECHA1231.1

Pumphrey, H. C., Santee, M. L., Livesey, N. J., Schwartz, M. J., \& Read, W. G. (2011). Microwave Limb Sounder observations of biomass-burning products from the Australian bush fires of February 2009. Atmospheric Chemistry and Physics, 11(13), 6285-6296. https://doi.org/10.5194/ acp-11-6285-2011

Radke, L. F., Lyons, J. H., \& Hobbs, P. V. (1990). Smokes from the burning of aviation fuel and their self-lofting by solar heating. Journal of Geophysical Research, 95, 14,071-14,076. https://doi.org/10.1029/JD095iD09p14071

Seftor, C. (2017a). Record breaking aerosol index values over Canada, NASA OMPS blog. Retrieved from https://ozoneaq.gsfc.nasa.gov/ omps/blog/2017/08/record-breaking-aerosol-index-value-over-canada, Accessed August 15.

Seftor, C. (2017b). Oregon PyroCbs produce large, high altitude smoke cloud, NASA OMPS blog. Retrieved from https://ozoneaq.gsfc.nasa. gov/omps/blog/2017/8/31/oregon-pyrocbs-produce-large-high-altitude-smoke, Accessed August 31.

Siddaway, J. M., \& Petelina, S. V. (2011). Transport and evolution of the 2009 Australian Black Saturday bushfire smoke in the lower stratosphere observed by OSIRIS on Odin. Journal of Geophysical Research, 116, D06203. https://doi.org/10.1029/2010JD015162

Torres, O., Bhartia, P. K., Herman, J. R., Ahmad, Z., \& Gleason, J. (1998). Derivation of aerosol properties from satellite measurements of backscattered ultraviolet radiation: Theoretical basis. Journal of Geophysical Research, 103, 17,099-17,110.

Vernier, J.-P., Pommereau, J. P., Garnier, A., Pelon, J., Larsen, N., Nielsen, J., ... McDermid, I. S. (2009). Tropical stratospheric aerosol layer from CALIPSO lidar observations. Journal of Geophysical Research, 114, D00H10. https://doi.org/10.1029/2009JD011946

Winker, D. M., Pelon, J., Coakley, J. A. Jr., Ackerman, S. A., Charlson, R. J., Colarco, P. R., ... Wielicki, B. A. (2010). The CALIPSO mission: A global 3D view of aerosols and clouds. Bulletin of the American Meteorological Society, 91(9), 1211-1230. https://doi.org/10.1175/ 2010BAMS3009.1 